\title{
A MIXED BATCH
}

ŚLACKI

PRZEGLAD

STATYSTYCZNY

Christian Westphal

Nr 18(24)

Philipps University of Marburg, Germany

(C) 2020 Christian Westphal

This work is licensed under the Creative Commons Attribution-ShareAlike 4.0 International License. To view a copy of this license, visit http://creativecommons.org/licenses/by-sa/4.0/

Quote as: Westphal, Ch. (2020). A mixed batch. Ślaski Przegląd Statystyczny, 18(24).

DOI: $10.15611 /$ sps.2020.18.22

JEL Classification: C51, H26, M42

This talk deals with six different topics of applications and research ideas.

First of all the author starts with a warning. Economists like elasticities. Hence, in regression analyses often ratios of variables, e.g. per capita variables of the form

$$
Y / Z=X / Z \cdot \beta+\varepsilon
$$

are used, but parameter estimators for models containing ratios of variables are usually biased, leading to spurious regressions.

The second topic is based on professional experience. One of the author's customers had a tax audit. The tax inspector tested the daily cash revenues for a log-normal distribution, and the test rejected a log-normal distribution. Hence, a tax fraud was assumed, but the assumption of a lognormal distribution for cash revenues was probably based on a book on tax auditing whose author misunderstood some statistical properties. It seems that the book interprets the probabilistic statement that a (mathematical) product of a multitude of random variables is (asymptotically) log-normal distributed erroneously as the result (product) of combining a variety of production factors (!) must be log-normal distributed. In a similar case in Austria the court consulted statisticians, and then decided that rejection of a log-normal distribution for cash revenues does not constitute a probable cause for tax fraud. However in Germany this test is still used in tax auditing.

The third topic also concerns the professional experience of the author. His mother has had a tax consultancy company, which he will take over. His mother is well liked, friendly, very empathic and selfless, but her son, the author, is an economist, hence he is familiar with economies of scale, 
price elasticity and self-selection. Thus, he replaced individualized services by standard services, leading to a decrease in workload and an increase in quality, which had no negative effect on the company. Furthermore, he increased the fees, since an increase of the fees by $\mathrm{x} \%$ leading to a decrease in demand by less than $\mathrm{x} \%$ results in higher profits. As additional effect of this increase was that he got rid of bad customers (labour-intensive and never satisfied) and their friends, and increases profits, too.

Afterwards some ideas for further research were presented. Analogies between traceability and reversibility of gun control and (bitcoin) blockchains were pointed out. Another issue was the question of optimal control frequency for tax audits. Depending on the company's size, the chance of being audited in Germany ranges between every five years to every 100 years. The author stated that considerations on frequencies of ticket inspections in public transport could be applied to this problem, but probably tax officers would not understand it. Finally, the question was asked if cryptanalysis could be a way to deal with missing data not at random, since both seem to deal with some more or less comparable problems.

\section{References}

Avenhaus, Krieger, Pick1. 2011. Spieltheoretische Modelle für berwachungsaufgaben. OR News 41: 15-18.

Hayo, B., Neumeier, F. \& Westphal, C. 2019. The social costs of gun ownership revisited. Empirical Economics, 56(1). https://doi.org/10.1007/s00181-018-1496-6

Kronmal, Richard A. 1993. Spurious Correlation and the Fallacy of the Ratio Standard Revisited. Journal of the Royal Statistical Society. Series A (Statistics in Society), 156(3): 379-392.

Keywords: spurious regression, tax auditing, control frequency. 